\title{
Czech Language and Literature
}

\author{
Peter Zusi
}

Recent years have seen a certain tendency to refer to Kafka as a 'Czech' author - a curious designation for a writer whose literary works, without exception, are composed in German. As the preceding chapter describes, Kafka indeed lived most of his life in a city where Czech language and society gradually came to predominate over the German-speaking minority, and Kafka - a native German-speaker - adapted deftly to this changing social landscape.

Referring to Kafka as Czech, however, is inaccurate, explicable perhaps only as an attempt to counterbalance a contrasting simplification of his complicated biography: the marked tendency within Kafka scholarship to investigate his work exclusively in the context of German, Austrian or Prague-German literary history. The Czech socio-cultural impulses that surrounded Kafka in his native Prague have primarily figured in Kafka scholarship through sociological sketches portraying ethnic animosity, lack of communication and, at times, open violence between the two largest linguistic communities in the city. These historical realities have given rise to the persistent image of a 'dividing wall' between the Czech- and Germanspeaking inhabitants of Prague, with the two populations reading different newspapers, attending separate cultural institutions and congregating in segregated social venues. This image of mutual indifference or antagonism has often made the question of Kafka's relation to Czech language and culture appear peripheral.

Yet confronting the perplexing blend of proximity and distance, familiarity and resentment which characterized inter-linguistic and intercultural contact in Kafka's Prague is a necessary challenge. Kafka himself (as well as many of his closest friends, such as Max Brod) actively defied the ethnic and cultural barriers characterizing early twentieth-century Prague by associating with Czech writers, following Czech cultural periodicals and attending Czech theatre presentations. Yet even Kafka's references to Czech culture show moments of striking intimacy surrounded by prominent 
silence. Any discussion of the significance of Czech language and literature for Kafka, therefore, must acknowledge both the intimacy and the silence.

\section{Kafka's Czech Proficiency}

Kafka spoke Czech quite fluently, but was not wholly bilingual. Kafka's family spoke German amongst themselves, though his parents and siblings all spoke Czech to varying degrees as well. (Kafka's youngest sister eventually married a Czech, and their family became effectively Czech-speaking.) Kafka's mother appears to have been less fluent than his father, who grew up in a south Bohemian village which was largely Czech-speaking, and in later life Hermann Kafka routinely spoke Czech with employees, and often with customers, at his shop (and he did not hesitate to use the Czech form of his name, 'Heřman', when it seemed commercially tactful).

Czech-speaking domestics and governesses were a consistent feature of Kafka's childhood and were probably the most important source of his early acquisition of the language. As a young man Kafka's proficiency in Czech was such that he was on occasion called upon to undertake sensitive negotiations in Czech with disgruntled employees of his father's shop. After the establishment of the Czechoslovak Republic in 19I8, Kafka's employer, the Arbeiter-Unfall-Versicherungs-Anstalt (Workers' Accident Insurance Institute), changed its language of operation to Czech, and many Germanspeaking employees were made redundant or gave notice of their own accord; Kafka, however, was not only able to retain his job but indeed continued to gain promotions in the Czech-speaking environment.

In his correspondence with the Czech author Milena Jesenská (I896I944) - one of the most famous epistolary romances in world literature Kafka insisted that Jesenská write to him in Czech, claiming that 'German is my mother-tongue ... but Czech feels to me far more intimate' ( $L M$ 26/BM I7). In his comments on the Czech translations Jesenská was producing of some of his work at the time, Kafka responded to the nuances of her Czech with subtlety and sensitivity. Jesenskás Czech translation of Kafka's story 'Der Heizer' ('The Stoker') appeared in the 22 April 1920 issue of the left-wing cultural journal Kmen. This was the first translation of Kafka's work into any language. Jesenskás translations of stories from Kafka's Betrachtung (Meditation) and of his 'Bericht für eine Akademie' ('Report to an Academy') appeared in the course of 1920, and her version of 'Das Urteil' ('The Judgement') was published in 1923. Kafka's own letters to Jesenská were in German, to be sure, and indeed even when he wrote 
business correspondence in Czech Kafka often asked his Czech brotherin-law to proofread for him, probably from awareness of the social and professional sensitivities of language-use at the time. Yet this insecurity also reflects the exorbitant self-criticism of a writer desiring utter command over every nuance in his written expression: Kafka could not write in Czech at the level of a Franz Kafka, but that is a demanding standard indeed.

\section{Kafka and the Czech Cultural Environment}

Kafka's knowledge of Czech literature and culture is less widely known, although this was a major component of 'the very air that Kafka breathed'. During his school years, Kafka - who attended exclusively Germanlanguage schools both at primary level and at the Gymnasium - chose to receive instruction in Czech that went well beyond the requirements stipulated by the curriculum and well beyond mere language instruction. His classes exposed him to an impressive overview of Czech history and classical Czech literature: ancient Czech myths from, among other sources, the so-called 'Forged Manuscripts' (purported to be medieval but in fact nineteenth-century falsifications), extracts from the seventeenth-century philosopher Jan Amos Komenský (1592-1670), texts by major representatives of the Czech National Revival (such as Jan Kollár, František Ladislav Čelakovský and František Palacký), Czech Romanticism (such as Karel Hynek Mácha, Karel Jaromír Erben and Božena Němcová) and even nearcontemporary Czech authors (such as Jan Neruda, Karolína Světlá, Jaroslav Vrchlický, Julius Zeyer, Svatopluk Čech and Alois Jirásek).

Remarkably, given the social tensions of the period, the Germanlanguage Gymnasium Kafka attended used the same anthologies of Czech literary and historical texts used in Czech schools; students were thus presented with 'an extremely detailed chronological exposition of the Czech National Revival in its various phases'. ${ }^{2}$ Kafka received excellent grades in these classes and demonstrably drew on these educational foundations later in life, such as in his famous diary entry on 'small literatures' or through his continuing interest in Božena Němcová's (I82O-62) novels and correspondence.

Beyond this formal education Kafka continued throughout adulthood to read original works of Czech literature as well as Czech translations of French or English texts, to subscribe to or at least occasionally peruse a broad and eclectic range of Czech cultural periodicals, to follow current events in Czech politics, and to maintain acquaintances with a number 
of Czech authors (such as the brothers Jiří and František Langer, Fráňa Šrámek or Michal Mareš). Several of Kafka's closest friends, including Max Brod, were proficient in both languages and took an active interest in supporting cultural contacts among Czech- and German-language writers and artists. Thus, for example, Kafka was certainly familiar with the work of the most significant poet of Czech Symbolism, Otokar Březina (I868-1929), as Kafka's own publishing house, Kurt Wolff Verlag, published several volumes of Březina's poetry in translations by Otto Pick, Emil Saudek and Franz Werfel, whom Kafka knew.

These facts are isolated, but that they add up to more than the parts is revealed by an episode Kafka relates in a letter to Jesenská, which says much about his intuitive awareness of contemporary Czech literature. Discussing an issue of the sharply left-wing Czech cultural journal Kmen he had perused ${ }^{3}$ - the same journal in which Jesenskás translation of his story 'Der Heizer' ('The Stoker') had recently appeared - Kafka relates that the 'first good piece of original work' he read there was a story by a writer named Vladislav Vančura, 'or something like that' ( $B M, 228)$. Kafka had the name quite right, and the writer well pegged: while at that time Vančura (I89I-I942) was barely known, he would emerge over the next few years as one of the most original and significant voices of Czech modernist prose.

\section{Kafka and Contemporary Czech Authors: Beyond the Anxiety of Influence?}

Such evidence of Kafka's conversancy with Czech culture, however, is distinctly tempered by the gaps that surround it. Kafka never mentioned even in passing, for example, the work of the great Czech-Jewish modernist Richard Weiner (1883-1937), even though Weiner was represented in Franz Pfemfert's anthology of Jüngste tschechische Lyrik (Recent Czech Lyric Poetry, 1916), to which several of Kafka's friends provided translations (in fact, Kafka may himself have assisted on some of these). Yet if there is any contemporary Czech author in whom one would expect Kafka to have taken an interest, surely it is Weiner, who in origin, in the social environment in which he grew up and lived, in his understanding of the world, in his aesthetic views, and in depth of talent' was closest to Kafka of any contemporary Czech author. ${ }^{4}$

Weiner came from a bourgeois, bilingual Jewish family background, and addressed in his work themes startlingly similar to Kafka's. Weiner's story 'Ruce' ('Hands', I9I8) can illustrate this affinity. A young man named Vít arrives at the house of a young woman named Marie. A servant tells him 
that Marie already has a visitor, but Vít brushes this off, declaring confidently that as an old friend of the family he is always welcome. Entering the parlour he finds Marie with Dr Sykora, whom he has never met but knows to be Marie's fiancé, an engagement entered into after only a brief acquaintance. Awkward silence makes clear that Vít has interrupted a quarrel between the couple; indeed, it turns out that they have just cancelled their engagement. Vít settles into the role of neutral mediator, assuming a fatherly tone and inquiring what possible reason there could be for this. The couple inform him sharply that he is to blame.

The body of the story serves to transform this seemingly preposterous accusation, this unspecified guilt, from absurdity into actuality. Gradually, a subliminal reality that Vít - trusted family friend - in fact desires Marie, that this desire is reciprocated, and that they both harbour selfish satisfaction seeing the unfortunate Dr Sykora destroyed by jealousy, becomes an irresistible dynamic. Whether this reflects the release of previously repressed feelings or the spontaneous generation of a new, alternative reality is unclear. As unconscious supplants conscious reality, the characters' hand gestures become the true agents of the narrative. But, as with Kafka, the unconscious does not drive the story in the direction of psychological parable; rather it provides a frame that makes startling and irrational developments appear logical and realistic. Vaguely defined guilt, the fragility of identities, latent sadism simmering under the surface of human interactions, the force of gestural language, and a blurred boundary between consciousness and the unconscious represent distinctly Kafkan moments in Weiner's story.

Another Czech author critics have compared to Kafka, yet about whom Kafka himself remained silent, is Jaroslav Hašek (I883-1923). Hašek's masterpiece, Osudy dobrého vojáka Švejka za svètové války (The Adventures of the Good Soldier Švejk during the World War, I92I-3), is often described as a picaresque novel, and the comic manner in which the dim or arguably deceptive title figure manages, paradoxically, to undermine belligerent authorities through mindless subordination to them seems at first to have little in common with the stubborn, despairing struggles depicted in Kafka's major fictions. Yet critics have noted a shared concern with the absurdity and inhumanity of the hyper-rationalized world: both Kafka and Hašek transform recognizably late-Habsburg bureaucratic machinery into a cipher for alienated modern life.

Different though they are, Kafka's and Hašek's protagonists manoeuvre amongst endless obstacles and relentless menace; indeed, no less a figure than Walter Benjamin noted that ' $\mathrm{K}$. has rightly been compared with the 
Good Soldier Švejk: the one is astonished at everything; the other at nothing.' 5 For many years the Kafka-Hašek comparison was fuelled by conjectures that the two authors might have met, or at least been present in the same room, during meetings of a Czech anarchist group in Prague in the years before the First World War, which seemed to confirm an underlying affinity between them. These speculations are now discredited. The early fame of Hašek's Švejk was due in no small measure to the efforts of Max Brod, who wrote an enthusiastic review of an early theatre adaptation of scenes from the novel, compared Hašek to Cervantes and Rabelais and (after Kafka's death) collaborated on a German-language stage adaptation of $\breve{s e j k}$ that enjoyed considerable success in Berlin in the late twenties. ${ }^{6}$ Kafka's silence in this case, therefore, is conspicuous.

Ironically, one of the few claims one might plausibly venture of direct influence of a work of Czech literature on Kafka is one of the most surprising, as it relates to Božena Němcová's (1820-62) Babička (Grandmother, I855) - a sentimental-realist novel presenting a largely idealized portrayal of Czech village life. Kafka's deep enthusiasm for the work is documented, and several critics have followed Brod's lead in identifying certain episodes from Babicka as an impulse to plot strands in Das Schloss (The Castle). ${ }^{7}$ That Kafka appears to have been captivated by this narrative world diametrically opposed to his own, that is, one based on harmony and reconciliation rather than hostility and alienation, has puzzled critics, and it has proved difficult to derive much significance from Brod's inferences beyond simply stating that in The Castle, 'Kafka inverts - and subverts - the idealized relations between the village and the manor house that obtain in Němcová's novel.'

Babicka, however, is not so relentlessly idealizing as such a claim implies, and is in fact shot through with elegiac or even ominous elements: the episodes narrating the Grandmother's difficult life in the past, for example, and especially the sub-plot of mad Viktorka, a girl from the village who was seduced and then abandoned. Viktorka kills her infant child and then in self-punishment denies herself the forgiveness of the community and shuns all human society, living like a frightened animal in the forest outside the village. Němcovás novel thus puts its own idealizing moments into question, and it is highly plausible that this tension is part of what drew Kafka to the work.

Here lies the conundrum in assessing Kafka's relationship to Czech literature. Kafka lavishly praised the writing of Nermcová, but ignored the work of Weiner. Kafka and Brod shared a strong interest in Nietzsche, but remained indifferent to the brilliant and eccentric Ladislav Klíma's 
(1878-1928) dramatic responses to Nietzsche's philosophy. Kafka possessed the militantly anti-German Slezské pisnè (Silesian Songs) by the Moravian poet Petr Bezruč (1867-1958) in German translation, but he read The Autobiography of Benjamin Franklin in Czech. ${ }^{9}$ Do such facts yield a coherent picture? The names from Czech culture one might reasonably expect to have been significant for Kafka are often absent from the documents of his life, while, conversely, the names that assume importance are not necessarily what one would anticipate. And in Kafka's only sustained statement relating to Czech literature, his diary entry on 'small literatures', there are absolutely no names at all: the 'small' literatures of Czech and Yiddish serve Kafka merely as icons of a particular relation between writer and community which he feels is inaccessible to him, a relation characterized by intimacy and mutual sustenance, but that presupposes a lack of significant talents' (25 December I9II; $D$ I49/TB 314). Kafka reflects here on 'Czech literature', not on Czech writers. Moreover, most of those reflections, portraying Czech literature as a tool for community-formation and ignoring developments towards literary modernism, were long out of date and 'do not apply to the period around I900', as Kafka would have known well. ${ }^{\text {Io }}$

The final twist in this discussion is that literary relevance to Kafka can appear even in cases where the 'dividing wall' image mentioned at the outset does indeed seem to apply. The example of Viktor Dyk (I877-193I) is a case in point. Dyk was not only one of the most prominent Czech authors contemporary with Kafka but was also an energetic activist for Czech independence and, after the establishment of an independent state, became a senator and prominent figure of the far right. While Dyk's version of Czech nationalism has its complexities, it was certainly strident - strident enough to land him in prison for treason during the First World War. While in prison, Dyk wrote perhaps his most famous poem, 'Země mluvi' ('The Earth Speaks', I918), which has often been taken as an emblematic literary statement of territorializing nationalism. His most famous prose work, Krysar (The Ratcatcher, 19II), is a re-working of the legend of the PiedPiper of Hamelin. What is striking, however, is how the title figure - with whom the author clearly identifies, though not uncritically - represents an archetypal outsider, without fixed abode and indeed without a name. (The first words we hear the Ratcatcher speak are 'I have no name. I am nobody. I am less than nobody. I am a ratcatcher.') ${ }^{\mathrm{II}}$ Like K. in The Castle, the Ratcatcher has intruded upon a closed community that regards him with suspicion (indeed, the stolid citizens of Hamelin attempt to renege on their contract with the Ratcatcher on the grounds that, as he has no name, his identity as signatory to the contract cannot be proven). 
The Ratcatcher is more powerful than K.: he successfully takes revenge, but at the cost of his life, since he, too, is lured by his own song into the abyss. Yet the exploration of outsiderhood, the critical view towards inward-looking communities and the recognition of uncertain identity as reflective of the modern condition - themes often associated in Kafka biographies with his status as German-speaking Prague Jew - are central to this novella by a nationalist Czech author as well.

\section{NOTES}

I M. Nekula, Franz Kafka and his Prague Contexts (Prague: Karolinum, 2016), p. 160. The following account draws heavily on the details Nekula provides in this fundamental study.

2 Nekula, Franz Kafka and his Prague Contexts, pp. I45-50: I48. See also pp. I5I95 of Nekula's study.

3 The Czech word Kmen is a loan-translation of the German Stamm, retaining the literal meaning of tree-trunk and the metaphorical meaning of tribe or group of people.

4 F. Kautman, 'Franz Kafka und die tschechische Literatur' in E. Goldstücker, F. Kautmann and P. Reimann (eds.), Franz Kafka aus Prager Sicht (Berlin: Voltaire Verlag, 1966), pp. 44-77: 66.

5 W. Benjamin, 'Franz Kafka: On the Tenth Anniversary of His Death' in M. W. Jennings, H. Eiland and G. Smith (eds.), R. Livingstone (trans.), Walter Benjamin: Selected Writings (Cambridge, MA: Harvard University Press, 1999), vol. II, pp. 794-8I6: 8I4. Translation modified.

6 See G. Vassogne, Max Brod in Prag: Identität und Vermittlung (Tübingen: Niemeyer, 2009), pp. 205-13.

7 See M. Brod, Über Franz Kafka (Frankfurt am Main: Suhrkamp, 1974), pp. 37I-4.

8 A. Thomas, Prague Palimpsest: Writing, Memory, and the City (University of Chicago Press, 2010), p. 98.

9 For details on Franklin, see Nekula, Franz Kafka and his Prague Contexts, p. I58; and J. Born, Kafkas Bibliothek: Ein beschreibendes Verzeichnis (Frankfurt am Main: Suhrkamp, 1990), p. I69. Bezručss Slezské pisně appeared in multiple, slightly diverging editions in the first decades of the twentieth century, and Rudolf Fuch's German translation (with a foreword by Franz Werfel) was published in 1917.

Io G. von Bassermann-Jordan, 'Franz Kafka, die "kleine Litteratur" und das Tschechische', Internationales Archiv für Sozialgeschichte der deutschen Literatur, 35, no. 2 (20IO), 98-I2I: I2O.

II V. Dyk, The Ratcatcher, trans. R. Kostovski (Washington, DC: Plamen Press, 20I4), p. I. 